\title{
AKIBAT PEMANGKASAN TASEL DAN DAUN DI BAWAH TONGKOL TERHADAP PRODUKSI BIJI JAGUNG ( Zea mays, L )
}

\author{
Surtinah \\ Fakultas Pertanian Universitas Lancang Kuning Pekanbaru Riau
}

\begin{abstract}
Seed maized have ability in piling up dry materials, but process that depended from result of photosynthesis conducted by leaf at the time of growth of vegetative and also at the time of generative growth, its problem do tasel also play a part in conglomeration of dry materials to seed. Object of this research is to get most precise maize crop organ clipping and give best maize seed production.

Research conducted by using random block design in factorial; first factor is pruning of tasel which consist of 2 level that is clipped and do not be clipped. Second factor is leaf pruning under cob which consist of 3 level that is without prunned, pruning 3 piece of leaf, and pruning entire leaf. Continued test used DNMRT at level $5 \%$ parameter perceived is dry wight of cob / crop (g), weigh of pipilan dry / crop (G). and wight 100 seed of pipilan dry / crop (g).

Result of research indicated that pruning of tasel can improve dry wight of cob / crop, weight of pipilan dry / crop, and wight 100 seed of pipilan dry.
\end{abstract}

Key words : vegetative, generative, pruning, tasel, cob

\section{PENDAHULUAN}

Jagung ( Zea mays, L. ) merupakan tanaman serealia penting di dunia . Berdasarkan urutan kepentingannya maka jagung menempati urutan ketiga setelah padi dan gandum. Di Indonesia jagung menempati urutan kedua setelah padi, dan mengandung zat gizi yang sangat tinggi, terutama karbohidrat yang terkandung di dalam biji jagung melebihi karbohidrat yang ada dalam padi. Permintaan jagung dari tahun ketahun meningkat, sedangkan kenaikkan produksi tidak secepat lonjakan kebutuhan. Produksi jagung di Indonesia tidak stabil, banyak faktor yang mempengaruhinya antara lain, varietas yang digunakan, hama dan penyakit, dan teknik budidaya yang belum memadai.
Produksi jagung di Riau tahun 2001 sebesar 39.915 ton, sedangkan kebutuhan untuk konsumsi sebesar 47.192,28 ton, ini

\section{J. Buana Sains Volume 5 Nomor 1 Juni 2005}

Propinsi Riau, 2002 ). Hal ini disebabkan karena benih yang digunakan dalam budidaya jagung belum sesuai dengan anjuran, masyarakat tani masih menggunakan varietas lokal atau benih yang digunakan adalah turunan pertama dari benih hibrida, sehingga hasilnya tidak dapat diharapkan. Padahal biji merupakan produksi dari tanaman jagung, dimana biji merupakan salah satu komponen hasil yang sangat penting.

Jagung hibrida mempunyai kemampuan untuk menimbun bahan kering lebih besar dibandingkan 
dengan varietas lokal. Hal ini merupakan salah satu faktor penting dalam proses produksi, aspek fisiologis yang mempengaruhi perkembangan biji belum banyak dibahas. Perkembangan biji jagung dipengaruhi oleh beberapa hal antara lain adalah kondisi tanaman sebelum berbunga dan kondisi tanaman setelah berbunga.

Bahan kering yang disuplai ke dalam biji merupakan hasil metabolisme tanaman, namun apakah asimilat yang ditimbun tersebut berasal organ di atas tongkol atau dari bawah tongkol atau dari kedua bagian tersebut. Dan apakah tasel berperan juga dalam pengisian bahan kering ke biji ? hal ini perlu ditelaah labih dalam. Organ vegetatif yang paling penting untuk pertumbuhan tanaman adalah daun, Surtinah ( 2005 ) melaporkan bahwa pemangkasan seluruh daun di atas tongkol setelah terjadi pembuahan dapat meningkatkan berat kering biji per tongkol, dan meningkatkan kecepatan penimbunan bahan kering ke biji. Bagaimana kalau pemangkasan dilakukan pada daun yang berada di bawah tongkol, apakah berat kering biji akan meningkat atau menurun ?, ini yang masih menjadi pertanyaan.

Goldworthy et al. ( 1996 ) menyatakan bahwa pembuangan tasel dapat meningkatkan hasil biji, untuk daerah tropik kenaikan sampai mencapai $17.5 \%-21 \%$. Asimilat yang digunakan untuk pengisian biji diperoleh dari tiga sumber utama yaitu fotosintesis daun saat sekarang, fotosintesis bagian lain yang bukan daun saat sekarang, dan remobilisasi hasil asimilasi yang disimpan dalam organ tanaman yang lain ( Gardner et al, 1991 ).
Bahan kering yang disimpan dalam biji berasal dari daun dan sebagian kecil berasal dari bahan yang tersimpan dalam batang sebagai hasil metabolisme sebelum tanaman berbunga. Oleh karena itu kerusakan daun pada saat berbunga atau setelah tanaman berbunga akan mengurangi suplai bahan kering ke biji. Lupton, ( 1966 ; Wardlaw, 1968 ) melaporkan bahwa daun-daun sebelah bawah tanaman gandum dan barli memasok kebutuhan batang sebelah bawah dan akar. Apabila daun-daun pucuk dibuang, daundaun sebelah bawah akan memasok hasil asimilasi ke biji; bila daun-daun sebelah bawah dibuang, daun bendera akan mentrasfer hasil asimilasi ke bagian bawah ( Marshall dan Wardlaw, 1973 ). Berdasarkan hal ini maka dilakukan pemangkasan daun tanaman jagung. Selain pemangkasan, daun tanaman jagung dapat berkurang atau rusak akibat tiupan angin dan hama pemakan daun pada saat biji sedang berkembang. Permasalahannya apakah dengan pemangkasan tersebut biji tanaman akan berkembang dengan baik ?

Sunaryono dan Rismunandar ( 1981 ) menyatakan pemangkasan daun merupakan salah satu cara untuk mengatur keseimbangan tanaman sehingga dapat memberikan pertumbuhan yang baik, melalui pemangkasan diharapkan sumbangan terhadap pengurangan bagian tanaman seperti jumlah daun dan bagian tanaman lainnya, sehingga dengan demikian pertumbuhan vegetatif tanaman dapat diseimbangkan dengan pertumbuhan generatif. Dari uraian di atas, maka dilakukan penelitian dengan memberikan Urea untuk meningkatkan pertumbuhan vegetatif 
jagung sehingga asimilat yang dihasilkan lebih besar, setelah terjadi pembuahan dilakukan pemangkasan, sehingga akan diketahui seberapa besar asimilat yang disimpan pada bagian vegetatif tanaman jagung disumbangkan untuk pertumbuhan biji.

Tujuan penelitian ini adalah untuk mendapatkan pemangkasan organ tanaman jagung yang paling tepat dan memberikan produksi biji jagung yang terbaik.

\section{BAHAN DAN METODA}

Bahan yang digunakan adalah benih jagung varietas Pioner 10, pupuk kandang sapi, Sevin, Furadan, Urea, SP 36, KCl.

Alat yang digunakan adalah alat-alat pengolahan tanah, timbangan analitik, pisau, gunting,

Penelitian dilaksanakan

secara eksperimen, dengan menggunakan Rancangan lingkungan adalah Rancangan Acak Kelompok dalam faktorial. Faktor pertama adalah Pembuangan tasel dan faktor kedua adalah pembuangan daundi bawah tongkol. Setiap unit perlakuan diulang 4 kali.

Pembunagan tasel terdiri dari dua taraf yaitu;

$\mathrm{T}_{1}=$ Tanpa dipangkas

$\mathrm{T}_{2}=$ Bunga jantan dipangkas

Pembuangan daun di bawah tongkol terdiri dari 3 taraf yaitu ;

$\mathrm{D}_{1}=$ Tanpa pemangkasan daun di bawah tongkol

$\mathrm{D}_{2}=$ Pemangkasan 3 helai daun di bawah tongkol

$\mathrm{D}_{3}=$ Pemangkasan seluruh daun di bawah tongkol.

Data pengamatan dianalisa dengan menggunakan sidik ragam dan dilanjutkan dengan uji DMRT pada taraf $5 \%$.
Model matematik yang digunakan adalah ;

$$
\mathrm{Y}_{\mathrm{ijk}}=\mu+\beta_{\mathrm{I}}+\theta_{\mathrm{j}}+\lambda_{\mathrm{k}}+
$$

J. Buana Sains Volume 5 Nomor 1 Juni 2005

Tanah di olah dengan menggunakan cangkul, sehingga diperoleh tanah yang gembur, selanjutnya dilakukan pembuatan plot dengan ukuran $1.2 \times 2.4 \mathrm{~m}$ dengan jarak antar bedengan 1 meter.

Benih ditugal dengan jarak tanam $100 \mathrm{~cm} \times 40 \mathrm{~cm}$, dengan kedalaman $4 \mathrm{~cm}$ dari permukaan tanah, masing-masing lubang diisi 3 butir.

Pemeliharaan tanaman meliputi penyiraman, penyiangan, penjarangan, pembumbunan, dan pemupukan. Pupuk dasar yang diberikan adalah pupuk kandang sebanyak $4.8 \mathrm{~kg}$ per plot. Pupuk Urea 6 g/tanaman, SP $36 \quad 7.2$ $\mathrm{g} /$ tanaman dan $\mathrm{KCl} 3.6 \mathrm{~g} /$ tanaman. Pupuk Urea diberikan 3 kali, yang kedua pada saat tanaman berumur 15 hari dengan dosis $6 \mathrm{~g} / \operatorname{tanaman}$, dan yang ketiga diberikan pada tanaman yang berumur 45 hari sebanyak 6 g/tanaman.

Pemangkasan daun di bawah tongkol dan bunga jantan dilakukan hanya terhadap satu tanaman per lubang tanam, dan pemangkasan dilakukan pada saat tasel muncul. Pemangkasan bunga jantan dengan cara menggoyangkan bunga jantan lalu ditarik, dan untuk pemangkasan daun dilakukan dengan menggunakan gunting.

Panen dilakukan dengan tanda-tanda sbb; kulit jagung sudah kering, daun juga mengering, biji kering mengkilap dan bila dipencet dengan kuku tidak berbekas. Setelah dipanen tongkol dikupas lalu dijemur selama 5 hari. 
Pengamatan dilakukan terhadap ; Bobot kering tongkol per tanaman ( $\mathrm{g}$ )Bobot kering tongkol ditimbang setelah tongkol dijemur selama 5 hari di panas terik; .Bobot kering pipilan kering / tanaman ( $\mathrm{g}$ ):

Pipilan kering ditimbang
ISSN 1412 - 1638 yang diambil dari tanaman sampel ; dan Bobot kering 100 biji pipilan kering ( $\mathrm{g}$ ): Biji yang ditimbang diambil dari pipilan kering sebanyak 100 butir.

\section{HASIL DAN PEMBAHASAN}

\section{Hasil Penelitian}

Tabel 1. Pengaruh utama Pemangkasan Tasel terhadap rata-rata bobot kering tongkol/tanaman, bobot kering pipilan/ tanaman, dan bobot 100 biji pipilan kering/tanaman..

\begin{tabular}{|l|c|c|c|}
\hline \multirow{2}{*}{$\begin{array}{c}\text { Pemangkasan } \\
\text { tasel }\end{array}$} & $\begin{array}{c}|c| \\
\text { Bobot kering } \\
\text { tongkol/tnm. }\end{array}$ & $\begin{array}{c}\text { Bobot kering } \\
\text { pipilan/tnm. }\end{array}$ & $\begin{array}{c}\text { Bobot 100 biji } \\
\text { ipilan kering/tnm }\end{array}$ \\
\hline Tanpa pmksn & $361.8 \mathrm{a}$ & $284.85 \mathrm{a}$ & $28.45 \mathrm{a}$ \\
Dengan pmksn & $388.05 \mathrm{~b}$ & $308.08 \mathrm{~b}$ & $32.49 \mathrm{~b}$ \\
\hline
\end{tabular}

Angka yang diikuti oleh huruf kecil yang tidak sama berbeda nyata pada taraf uji DMRT $5 \%$

Tabel 2. Pengaruh utama pemangkasan daun di bawah tongkol terhadap ratarata bobot kering tongkol/tanaman, bobot kering pipilan/tanaman, dan bobot 100 biji pipilan kering/tanaman

\begin{tabular}{|l|c|c|c|}
\hline \multirow{2}{*}{$\begin{array}{c}\text { Pemangkasan } \\
\text { daun di bawah } \\
\text { tongkol }\end{array}$} & $\begin{array}{c}\text { Bobot kering } \\
\text { tongkol/tnm. }\end{array}$ & $\begin{array}{c}\text { Bobot kering } \\
\text { pipilan/tnm }\end{array}$ & $\begin{array}{c}\text { Bobot 100 biji } \\
\text { pipilan krg/tnm }\end{array}$ \\
\cline { 2 - 4 } Tanpa pangkas & $378.87 \mathrm{a}$ & 235.68 & $31.45 \mathrm{a}$ \\
Pangkas 3 helai & $388.375 \mathrm{a}$ & 245.28 & $34.01 \mathrm{a}$ \\
Pangkas semua & $357.86 \mathrm{~b}$ & 227.56 & $25.94 \mathrm{~b}$ \\
\hline
\end{tabular}

Angka yang diikuti oleh huruf kecil yang sama tidak beda nyata pada taraf uji DMRT 5\%

Tabel 1. di atas memperlihatkan bahwa tanaman yang dipangkas taselnya bobot kering tongkol per tanaman, bobot kering piplan/tanaman, dan bobot 100 biji pipilan kering/tanaman lebih tinggi dibandingkan dengan tanpa pemangkasan. Begitu juga dengan Tabel 2. menunjukkan bahwa tanaman yang dipangkas seluruh daun di bawah tongkol hasil bobot kering tongkol per tanaman, bobot kering pipilan/tanaman, dan bobot 100 biji pipilan kering paling rendah dibandingkan dengan tanaman yang tidak dipangkas dan tanaman yang dipangkas 3 helai daunnya.

\section{Pembahasan \\ Pemangkasan Tasel}

Tasel tanaman jagung yang dipangkas memberikan hasil yang lebih baik dibandingkan dengan tasel yang tidak dipangkas untuk semua parameter yang dimati. Hal ini diperlihatkan oleh hasil uji rata-rata perlakuan dengan menggunakan uji lanjutan DMRT $5 \%$ Diduga kenaikan hasil akibat pemangkasan tasel ini karena dengan menghilangkan bagian pucuk tanaman maka fitohormon yang ada akan mengarahkan pertumbuhan ke bagian cabang, tongkol merupakan 
modifikasi dari cabang tanaman jagung, dimana tangkai tongkol merupakan modifikasi dari batang, kelobot merupakan modifikasi dari daun, dan biji jagung adalah perkembangan dari bunga. Kenaikan bobot kering tongkol per tanaman sampai $26.25 \mathrm{~g}$, untuk bobot kering pipilan per tanaman pemangkasan tasel meningkatkan hasil $23.23 \mathrm{~g}$, bobot 100 biji pipilan kering meningkat sebesar $4.04 \mathrm{~g}$ per tanaman. Peningkatan tersebut dapat juga disebabkan oleh terhentinya pengiriman asimilat ke tasel karena tasel tidak ada sehingga asimilat yang ada dikirim hanya ke bagian generatif yang membutuhkan yaitu biji. Asimilat yang dikirim ke biji adalah asimilat yang dihasilkan pada masa pertumbuhan vegetatif yang disimpang di bagian batang tanaman jagung, dan asimilat yang dihasilkan pada saat pengisian biji. Asimilat yang dihasilkan pada saat pengisian biji, jika dihubungkan dengan pemangkasan tasel dapat dijelaskan sebagai berikut, bila tasel tidak dipangkas maka akan menutupi sebagian daun pada saat matahari terik, sehingga kebutuhan cahaya akan berkurang untuk melakukan fotosintesis karena ada bagian daun yang ternaungi oleh bayangan tasel, hal ini tidak terjadi pada tanaman yang dipangkas, seluruh daun bendera terkena cahaya. Daun bendera merupakan pemasok asimilat terbanyak selama periode pengisian biji. Goldwarthy dan Fisher ( 1996 ) berpendapat bahwa kenaikan hasil yang disebabkan oleh pembuangan tasel ada hubungannya dengan jumlah cahaya yang sampai ke permukaan daun. Gardner ( 1991 ) menyatakan bahwa pada tanaman gandum dan barli, fotositesis dari daun bendera, batang dan bongkol yang merupakan sumber sumber terdekat dengan biji menjadi penyumbang utama untuk biji.

\section{Pemangkasan daun di bawah tongkol}

Tanaman jagung yang seluruh daun di bawah tongkol dipangkas dengan tanaman yang tidak dipangkas memperlihatkan bobot kering tanaman yang tidak nyata, begitu juga terhadap bobot 100 biji pipilan keringnya, namun untuk bobot kering pipilan per tanaman pemangkasan daun tidak menunjukkan beda nyata.

Bobot kering tongkol per tanaman yang dipangkas 3 helai daun di bawah tongkol menunjukkan peningkatan hasil sebesar $9.788 \mathrm{~g}$ dibandingkan dengan tanaman yang tidak dipangkas daunnya, dan kenaikkan akan lebih tinggi yaitu sebesar $20.73 \mathrm{~g}$ bila dibandingkan dengan tanaman yang dipangkas seluruh daun bagian bawah tongkol. Sedangkan untuk berat 100 biji pipilan kering kenaikan hasil mencapai $8.07 \mathrm{~g}$ bila dibandingkan antara tanaman yang daunnya dipangkas 3 helai dengan

tanaman yang daun di bawah tongkol dipangkas seluruhnya, tetapi kenaikan hanya mencapai $2.56 \mathrm{~g}$ bila dibandingkan dengan tanaman yang daunnya tidak dipangkas.

Daun tanaman jagung yang dipangkas 3 helai di bagian bawah tongkol menunjukkan hasil yang tinggi. Hal ini berarti bahwa daun di bawah tongkol terbukti memberikan pasokan asimilat ke tongkol dan biji, bila dibandingkan dengan tanaman yang daun bagian bawah tongkol dipangkas seluruhnya. Sementara pada tanaman yang daunnya tidak dipangkas diduga terjadi kompetisi untuk memperebutkan asimilat, 
dimana asimilat digunakan oleh daun untuk proses respirasi. Tanaman yang daunnya dipangkas 3 helai, diperkirakan daun-daun yang dibuang tersebut telah meremobilisasi asimilat ke bagian yang lebih muda atau ke daerah yang pemanfaatkan yaitu biji, jadi dengan pemangkasan yang dilakukan tidak berpengaruh apa-apa karena daun tersebut memang tidak produktif lagi, tidak produktifnya daun bisa disebabkan karena memang sudah tua atau karena terlindung oleh daun di sebelah atas, dan biasanya daundaun disebelah bawah ukurannya lebih kecil dibandingkan dengan daun di bagian tengah batang tanaman, sehingga apabila daun tersebut masih aktif asimilat yang dihasilkannya juga tidak banyak mungkin hanya cukup untuk digunakan oleh daun itu sendiri. Gardner et al ( 1991 ) menyatakan bahwa apabila terjadi penuaan pada daun, maka daun tidak akan mengekspor atau mengimpor hasil asimilasi, sebelum mati, banyak senyawa organik maupun anorganik dalam daun dimobilisasi kembali dan ditranslokasikan ke bagian tanaman yang lain. Pada tanaman yang seluruh daun di bawah tongkol dibuang hasil biji paling sedikit hal ini disebabkan asimilat yang harusnya dikirim ke biji harus dikirim juga ke bagian bawah tanaman di bawah tongkol seperti batang akar, sehingga asimilat terbagi tidak hanya untuk pengisian biji tetapi juga untuk mempertahankan kelangsungan hidup bagian bawah tanaman. Marshall dan Wardlaw ( 1973 ) mengemukakan apabila daun-daun pucuk dibuang, daun-daun sebelah bawah akan memasok hasil asimilasi ke biji, bila daun-daun sebelah bawah dibunang, daun bendera akan mentranspor hasil asimilasi ke akar.

\section{Pemangkasan tasel dan pemangkasan daun di bawah tongkol}

Tabel lampiran 3. 4.5 . memperlihatkan interaksi antara pemangkasan tasel dan daun di bawah tongkol tidak nyata. Hal ini akan lebih mudah bila dijelaskan dengan menggunakan grafik dari hasil statistik seperti yang tertera pada Gambar 1. samp (1) engan Gambar 6. di bawah ini.

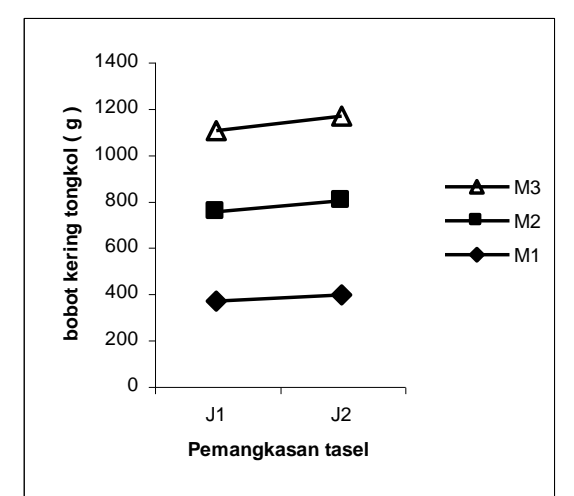

Gambar 1. Grafik interaksi antara pemangkasan daun dengan pemangkasan tasel terhadap bobot kering tongkol per tanaman. 
Gambar 2. Grafik interaksi antara pemangkasan tasel dengan pemangkasan daun terhadap bobot kering tongkol per tanaman
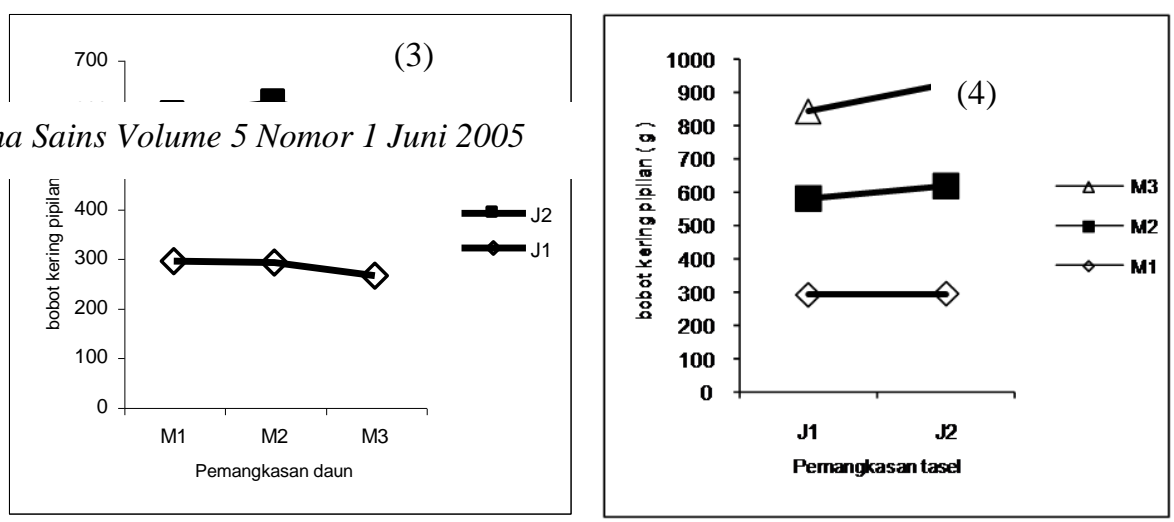

Gambar 3. Grafik interaksi antara pemangkasan daun dengan pemangkasan tasel terhadap bobot kering pipilan per tanaman

ISSN 1412 - 1638

Gambar 4. Grafik interaksi antara pemangkasan tasel dengan pemangkasan daun terhadap bobot kering pipilan per tanaman
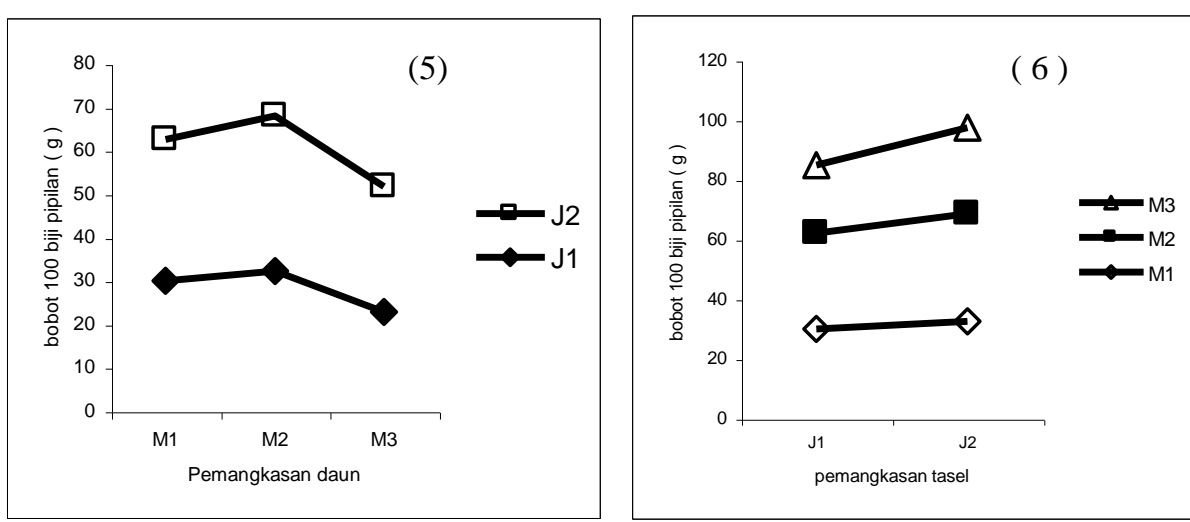

Gambar 5. Grafik interaksi antara pemangkasan daun dengan pemangkasan tasel terhadap bobot 100 biji pipilan kering per tanaman

Gambar 6. Grafik interaksi antara pemangkasan tasel dengan pemangkasan daun terhadap bobot kering pipilan per tanaman

Gambar 1. Gambar 3 dan Gambar 5. terlihat bentuk interaksi antara pemangkasan daun dan pemangkasan tasel. Pemngkasan tasel pada beberapa taraf pemangkasan daun menunjukkan peningkatan yang baik terhadap bobot kering tongkol, dan bobot 100 biji pipilan kering begitu juga pemangkasan daun beberapa taraf pemangkaSan tasel memperlihatkan kenaikan hasil yang cukup tinggi. Namun kenaikan hasil yang disebabkan oleh pemangkasan taSel pada beberapa taraf pemangkasan daun adalah sama, sehingga kedua garis terSebut menunjukkan garis sejajar atau hampir sejajar, dalam bidang statistik bila kenaikan hasil membentuk garis yang sejajar maka dinyatakan kenaikan hasil tersebut tidak nyata. Bila ditinjau dari ilmu fiSiologi tanaman, jelaS terlihat interaksi antara kedua perlakuan tersebut adalah nyata, dimana tanaman yang dipangkas taselnya pada beberapa taraf pemangkasan daun memperlihatkan kenaikan hasil yang 
cukup signifikan dibandingkan dengan tanaman yang taselnya tidak dipangkas pada taraf pemangkaSan daun yang sama.

Gambar 2. Gambar 4, dan Gambar 6, memperlihatkan Grafik hubungan antara pemangkasan daun pada beberapa taraf pemangkasan tasel juga memperlihatkan hal yang sama, dimana tanaman yang dipangkas seluruh daun di bawah tongkol, bobot kering tongkol, bobot kering pipilan, dan bobot 100 biji pipilan kering paling rendah bila dibandingkan dengan tanaman yang dipangkas daunnya sebanyak 3 helai, dan tanpa pemangkasan daun di bawah tongkol. Uji Statistik menunjukkan interaksi antara kedua faktor perlakuan tidak nyata, hal ini seperti fenomena di atas bahwa kenaikan haSil akibat taraf perlakuan yang bebrbeda adalah sama, maka akan diperlihatkan dalam bentuk garis sejajar.sehingga kenaikan hasil dianggap sama, itulah Sebabnya uji statistik menyatakan kenaikan haSil akibat perlakuan yang berbeda adalah tidak nyata. Kalau ditinjau Secara seksama bahwa pemangkaSan Seluruh daun dan 3 helai daun pada taraf pemangkasan tasel menunjukkan kenaikan hasil, dimana pemangkasan 3 helai daun di bawah tongkol memberikan hasil yang terbaik terhadap bobot kering tongkol.

Pemangkasan 3 helai daun pada taraf pemangkasan tasel bila dibandingkan dengan pemangkasan seluruh daun di bawah tongkol, lebih baik hasilnya hal ini disebabkan karena daun-daun di bawah tongkol yang masih tersisa memberikan sumbangan dalam pengisian biji, oleh karena itu maka organ generatif yang diamati seluruhnya memperlihatkan hasil yang terbaik pada perlakuan ini. Begitu juga pemangkasan tasel pada taraf pemangkasan daun menunjukkan hasil yang terbaik bila dibandingkan dengan pemangkasan seluruh daun di bawah tongkol dan tanpa pemangkasan tasel pada taraf pemangkasan daun. Pemangkasan daun pada beberapa taraf pemangkasan taSel memperlihatkan bentuk garis yang berpotongan seharusnya interaksi antara pemangkasan daun dan pemangkasan tasel adalah nyata, namun dalam hal ini tidak demikian yang terjadi, kenaikan hasil akibat pemangkasan tasel pada pemangkasan 3 helai daun tidak nyata bila dibandingkan dengan pemangkasan tasel pada taraf pemangkasan seluruh daun di bawah tongkol karena membentuk garis yang hampir Sejajar, kenaikan hasil yang diperlihatkan oleh taraf pemangkasan tasel pada tanaman yang daunnya tidak dipangkaS kecil sekali, diduga kenaikan ini diabaikan. Hal ini juga diduga karena distribuSi asimilat pada tanaman yang daunnya tidak dipangkas pada taraf pemangkasan tasel tidak mutlak dikirim ke biji Sehingga masih ada terjadi kompetisi di dalam tubuh tanaman itu sendiri dalam menggunakan asimilat. Daundaun yang tidak dipangkas pada beberapa taraf pemangkasan tasel juga masih melakukan proses fisiologis, sementara daun-daun di bawah tongkol tersebut tidak produktif karena daun-daun tersebut tidak penuh menerima cahaya matahari. Hal ini sesuai seperti yang pernah dilaporkan oleh Gardner et al. ( 1991); Goldwarthy et al. 1996; Kiniry et.al, 1990 ) bahwa pemangkasan organ-organ tanaman Seperti taSel dan daun dapat meningkatkan hasil. Indiarto (1995) 
melaporkan bahwa bila pembuangan daun terlalu banyak maka luas organ fotosintesiS akan menurun, besarnya penurunan organ fotosintesis mengakibatkan penuruan hasil.

\section{KESIMPULAN DAN SARAN Kesimpulan}

Tasel yang dipangkas akan meningkatkan bobot kering tongkol per tanaman sebesar $26.25 \mathrm{~g}$ per tanaman, bobot kering pipilan per tanaman sebesar $23.23 \mathrm{~g}$, dan bobot 100 biji pipilan kering sebesar 4.04 g.

Daun tanaman jagung di bawah tongkol yang dipangkas 3 helai dapat meningkatkan bobot kering tongkol per tanaman sebesar $30.52 \mathrm{~g}$, bobot pipilan kering sebesar $22.15 \mathrm{~g}$, dan bobot 100 biji pipilan kering sebesar $8.07 \mathrm{~g}$.

Interaksi antara pemangkasan tasel pada beberapa taraf pemangkasan daun , dan pemngakasan daun pata taraf pemangkasan tase tidak nyata memberikan kenaikan hasil terhadap bobot kering tongkol per tanaman, bobot pipilan kering per tanaman, dan bobot 100 biji pipilan kering. Namun interaksi antara pemangkasan tasel pada taraf pemangkasan 3 helai daun di bawah tongkol, dapat meningkatkan hasil biji jagung.

\section{Saran}

Saran yang dapat diberikan ialah untuk budidaya jagung, pemangkasan tasel dan pemangkasan 3 helai daun di bawah tongkol dianjurkan karena dapat meningkatkan hasil.

\section{DAFTAR PUSTAKA}

Andrade, F. H., C. Vega, S. Uhart, A. Cirilo, M. Cantarero, and O. Valentinuz, 1999. Kernel number determination in maize. Crop Sci. 39 : $453-$ 459.
Badan Ketahan Pangan Propinsi Riau, 2002. Pekanbaru.

Departemen Pertanian, 1990. Sub Dinas Penyuluhan Pertanian Tanaman Pangan Propinsi Riau.

Gardner, F. P., R. Brent Perce, Roger L. Mitchell, 1991. alih bahasa Herawati Susilo. Fisiologi Tanaman Budidaya. Universitas Indonesia.

Goldwothy, P. R., N. M. Mitchel, 1996. Physiology of Crop Plant . Alih bahasa Sri Andani dan Purbayanti. Universitas Gajah Mada. Yogyakarta.

Indiarto, 1995. Respon jagung terhadap populasi, Persentase dan posisi defoliasi jagung dan kacang tanah. J. Agroland $2: 6$.

Kiniry, J. R., C. A. Wood, D. A. Spanel, dan A. J. Bockhoft, 1990. Seed weight respons to decreased seed number in maize. Agron. J. $54: 98-$ 102.

Lupton, F. G. H., 1966. Ann. Appl. Biol 57 : $355-64$.

Marshall, C., dan I. F. Wardlaw, 1973. Aust. J. Biol. Sci. 26 $: 1-13$.

Surtinah, $2005 . \quad$ Hubungan pemangkasan organ bagian atas Tanaman Jagung ( Zea mays,L ) dan dosis Urea terhadap pengisian biji). Jurnal Ilmiah Pertanian. Volume 1. Nomor 2. Halaman $27-35$.

Sunaryono, H. dan Rismunandar, 1981. Pengantar Pengetahuan Dasar Hortikultura. CV. Sinar Baru. Jakarta. 
